\title{
Serological and molecular investigation of viral agents in free- living jaguars of the Pantanal wetlands, state of Mato Grosso, Brazil
}

\author{
Investigação sorológica e molecular de agentes virais em onças-pintadas de vida livre no \\ Pantanal de Mato Grosso, Brasil
}

\author{
Selma Samiko Miyazaki ONUMA ${ }^{1,5}$; Luciana Botelho CHAVES ${ }^{2}$; Maria do Carmo Custódio de Souza \\ Hunold LARA ${ }^{3}$; Joares Adenilson MAY-JÚNIOR ${ }^{4}$; Isis Indaiara Gonçalves Granjeiro TAQUES ${ }^{5}$; Juliana Torres \\ Tomazi FRITZEN ${ }^{6}$; Amauri Alcindo ALFIERI ${ }^{6}$; Tatiana OMETTO $^{7}$; Edison Luis DURIGON ${ }^{7}$; Jansen de \\ ARAÚJO $^{7}$; Daniel Luis Zanella KANTEK ${ }^{1}$; Daniel Moura de AGUIAR ${ }^{5}$ \\ ${ }^{1}$ Instituto Chico Mendes de Conservação da Biodiversidade, Estação Ecológica de Taiamã, Cáceres - MT, Brazil \\ ${ }^{2}$ Instituto Pasteur, São Paulo - SP, Brazil \\ ${ }^{3}$ Instituto Biológico, São Paulo - SP, Brazil \\ ${ }^{4}$ Universidade do Sul de Santa Catarina, Tubarão - SC, Brazil \\ ${ }^{5}$ Universidade Federal de Mato Grosso, Hospital Veterinário, Laboratório de Virologia e Rickettsioses, Cuiabá - MT, Brazil \\ ${ }^{6}$ Universidade Estadual de Londrina, Departamento de Medicina Veterinária Preventiva, Londrina - PR, Brazil \\ ${ }^{7}$ Universidade de São Paulo, Instituto de Ciências Biomédicas II, Departamento de Microbiologia, São Paulo - SP, Brazil
}

\begin{abstract}
This study investigates the exposure of free-living jaguars from two federal protected areas in the Pantanal of Mato Grosso, Brazil, to a variety viral agents. These viral agents, particularly causing zoonotic diseases, were analyzed using serological and molecular methods. None of the jaguars was positive by RT-PCR for the molecular detection of avian influenza and West Nile Fever (WNF). Only one animal was serologically positive for Eastern Equine Encephalitis (EEE) by virus neutralization test in VERO cell cultures, representing the first reported case of jaguar exposure to EEE virus. However, all the animals were negative for Western Equine Encephalitis (WEE) virus and Venezuelan Equine Encephalitis (VEE) virus. Eleven jaguars were tested by two tests for the detection of antibodies against rabies virus (Simplified Fluorescent Inhibition Microtest - SFIMT and Rapid Fluorescent Focus Inhibition Test - RFFIT), resulting in five positive animals, two animals in each test and one in both serological tests. Furthermore, three out of 14 samples subjected to the neutralization test were positive for antibodies against canine distemper virus (CDV), and 15 out of 17 samples subjected to the hemagglutination-inhibition test (HI) were positive for antibodies against canine parvovirus (CPV). In view of the findings of this study, it is unlikely that the viruses examined here represent a threat to the jaguar populations in this region.
\end{abstract}

Keywords: Panthera onca. Diagnostic. Protected areas. Wild felids. Brazil.

\begin{abstract}
Resumo
Este estudo investigou a exposição de onças-pintadas de vida livre a agentes virais selecionados em duas unidades de conservação federais no Pantanal de Mato Grosso, Brasil. Para a análise desses agentes virais, a maioria de caráter zoonótico, foram utilizados métodos sorológicos e moleculares. Nenhuma das onze onças-pintadas examinadas foi positiva na técnica de real-time RT-PCR para a detecção molecular dos agentes da Influenza aviária e Febre do Nilo Ocidental (WNF). Somente um animal foi positivo sorologicamente para a o vírus da Encefalite Equina do Leste (EEE) pela Microtécnica de vírus neutralização em culturas de células VERO, sendo este o primeiro relato da exposição de onças-pintadas. Todos os animais examinados s foram negativos para o vírus da Encefalite Equina do Oeste (WEE) e Venezuelana (VEE). Amostras de soro colhidas de 11 onças-pintadas foram submetidas a adois testes distintos para a detecção de anticorpos contra $\mathrm{o}$ vírus da raiva (Teste Rápido de Inibição de Foco de Fluorescência - RFFIT e Microteste Simplificado de Inibição da Fluorescência - SFIMT), resultando em cinco animais positivos, dos quase dois positivos para cada teste e um positivo quando submetido aos dois testes sorológicos. Além disso, três das 14 amostras submetidas a técnica de soroneutralização foram positivas para a pesquisa de anticorpos contra o vírus da cinomose (CDV) e 15 amostras positivas das 17 analisadas para a pesquisa de anticorpos contra o parvovírus canino (CPV) foram identificadas pela técnica de Inibição da Hemaglutinação (HI). De acordo com os resultados deste estudo, é pouco provável que os agentes virais aqui analisados representem ameaça à população de onçaspintadas nesta região.
\end{abstract}

Palavras-chave: Panthera onca. Diagnóstico. Áreas protegidas. Felinos selvagens. Brasil. 
Correspondence to:

Selma Samiko Miyazaki Onuma

Estação Ecológica de Taiamã, Instituto Chico Mendes de Conservação da Biodiversidade- ICMBio

Avenida Getúlio Vargas, s/n

CEP 78200-000, Cárceres, Mato Grosso, Brazil

e-mail: selma.onuma@icmbio.gov.br

Received: 23/12/2015

Approved: 01/06/2016

\section{Introduction}

Human intervention and ecological factors have given rise to new relationships between wildlife, domestic animals and humans, modifying the dynamics of infectious diseases and the geographic distribution of pathogens, which can result in outbreaks among wildlife. Although protected areas often offer the best prospects for the preservation of populations of many large felids, the boundaries of these areas are hotspots of conflict between large felids and people (MUNSON et al., 2008), increasing exposure to pathogens due to closer contact among wildlife, domestic animals and humans. This has been a concern for conservation authorities in their efforts to reduce the risks of disease transmission, which may affect wildlife species populations and also people living in their proximities.

Canine distemper virus (family Paramyxoviridae, genus Morbillivirus) is known to infect a variety of species of the order Carnivora (WILLIAMS, 2001). In the last few decades, this single-stranded RNA virus has contributed to the decline of several wildlife species as well as populations of free-ranging felids (ROELKE-PARKER et al., 1996; MUNSON et al., 2008; DAOUST et al., 2009; SEIMON et al., 2013). This, allied to illegal hunting and continual loss of habitat, could represent an important threat to the conservation of endangered species.

On the other hand, zoonotic viruses maintained by wildlife reservoir hosts still need further investigations in view of the emergence of cross-species virus transmission (CHILDS, 2004). This, in turn, may result in new patterns that favor the geographical spread of pathogens, significantly increasing the impact of viral diseases on animal populations and on humans. The extended host range of rabies virus (family Rhabdoviridae, genus Lyssavirus), West Nile virus (WNV) (family Flaviviridae, genus Flavivirus), equine encephalitis virus [Eastern (EEEV), Western (WEEV) and Venezuelan (VEEV)] (family Togaviridae, genus Alphavirus) and influenza A virus (AIV) (family Orthomyxoviridae, genus Influenza A) has kindled interest in new public health activities and wildlife conservation research.

The focus of this study was to detect and investigate the circulation of the viral agents CDV and parvovirus, with special attention to the zoonotic rabies-related viruses WNV, IV, EEEV, WEEV and VEEV in free-living jaguars in two protected areas in the northern Pantanal wetlands in Brazil.

\section{Material and Methods}

Samples were obtained from the Biological Sample Bank of Brazil's National Center for Research and Conservation of Carnivorous Mammals (CENAP/ ICMBio). Blood samples were collected from 21 jaguars captured between July 2010 and November 2014 at two federal conservation units (Taiamã Ecological Station - 16 $50^{\circ} 34.31^{\prime \prime}$ S, 57 $35^{\prime} 03.70^{\prime \prime} \mathrm{W}$, and Pantanal Matogrossense National Park $17^{\circ} 50^{\prime} 47.33^{\prime \prime} \mathrm{S}, 57^{\circ} 24^{\prime} 12.67^{\prime \prime} \mathrm{W}$ ) in the northern part of the Pantanal biome, which have great influence on ecological processes (MAMEDE; ALHO, 2006). The animals were immobilized with a combination of tiletamine and zolazepam (Zoletil $100^{\circ}$, Virbac SA, Carros-Cedex, France) and fitted with radio collars. After undergoing a clinical examination and sample collection procedures, all the animals were released at the sites where they were captured (under permit nos. 30896-1 and 18699-1 issued by the Biodiversity Authorization and Information System - SISBIO).

Due to limited serum quantities and opportunity to develop the analyses, not all tests were performed on all captured jaguar. To determine the exposure of 14 jaguars to $\mathrm{CDV}$, the virus neutralization assay 
(APPEL; ROBSON, 1973) with the Lederle strain was used, and titers of $\geq 8$ were considered positive (COURTENAY et al., 2001). For the detection of antibodies against CPV, serum samples from the aforementioned 17 jaguars were analyzed by the hemagglutination inhibition (HI) test, as described by Carmicheal et al. (1980), using as antigen the vaccine strain CPV-2b. The cut-off adopted was a dilution of 1:80.

To identify exposure to rabies virus, 11 serum samples were screened by the simplified fluorescent inhibition microtest (SFIMT), as described by Favoretto et al. (1993), and the rapid fluorescent focus inhibition test (RFFIT) (SMITH et al., 1996). Serum samples were analyzed twice on different days. Samples with rabies virus neutralizing antibodies (VNA) titers $\geq 0.10 \mathrm{IU} / \mathrm{mL}$ were considered positive
(JORGE et al., 2010). Samples from 11 jaguars were examined by seroneutralization assay performed on VERO cells to detect antibodies against EEE, WEE and VEE (KOTAIT et al., 1992), and titers of $\geq 5$ were considered positive.

A molecular analysis was performed to detect WNV and AIV by one-step real-time polymerase chain reaction (RT-PCR), using specific primers and conditions specified by several authors (OMETTO et al., 2013; ARAÚJO et al., 2014). RNA extraction was performed using a 5x MagMaxTM - 96 Viral Isolation Kit and an AgPath-IDTM One-Step RT-PCR Kit, according to the manufacturer's instructions (Ambion, Inc., Austin, TX, USA). RT-PCR was performed in an ABI 7300 PCR System (Applied Biosystems, Foster City, CA, USA).

Table 1 - Capture sites and results of serological assays of canine distemper virus, parvovirus, rabies and eastern equine encephalitis virus performed on blood sera of free-living jaguars (Panthera onca) from the Pantanal wetland biome in the state of Mato Grosso, Brazil - 2010-2014

\begin{tabular}{|c|c|c|c|c|c|c|c|c|}
\hline \multirow{2}{*}{ Jaguar } & \multirow{2}{*}{ Site } & \multirow{2}{*}{ CDV } & \multirow{2}{*}{ CPV } & \multicolumn{4}{|c|}{ Rabies virus } & \multirow{2}{*}{ EEE } \\
\hline & & & & \multicolumn{2}{|c|}{ SFIMT } & \multirow{2}{*}{\multicolumn{2}{|c|}{$\begin{array}{r}\text { RIFFT } \\
\mathrm{N}\end{array}$}} & \\
\hline 1 & PMNP & -- & -- & 0,19 & 0,12 & & & $\mathrm{~N}$ \\
\hline 2 & PMNP & $\mathrm{N}$ & -- & $\mathrm{N}$ & $\mathrm{N}$ & $\mathrm{N}$ & $\mathrm{N}$ & $\mathrm{N}$ \\
\hline 3 & PMNP & $\mathrm{N}$ & 160 & $\mathrm{~N}$ & $\mathrm{~N}$ & $\mathrm{~N}$ & $\mathrm{~N}$ & $\mathrm{~N}$ \\
\hline 4 & PMNP & -- & -- & $\mathrm{N}$ & $\mathrm{N}$ & $\mathrm{N}$ & $\mathrm{N}$ & $\mathrm{N}$ \\
\hline 5 & TES & $\mathrm{N}$ & 80 & $\mathrm{~N}$ & $\mathrm{~N}$ & $\mathrm{~N}$ & $\mathrm{~N}$ & $\mathrm{~N}$ \\
\hline 6 & TES & $\mathrm{N}$ & 80 & $\mathrm{~N}$ & $\mathrm{~N}$ & $\mathrm{~N}$ & 0,10 & $\mathrm{~N}$ \\
\hline 7 & TES & $\mathrm{N}$ & 80 & $\mathrm{~N}$ & $\mathrm{~N}$ & $\mathrm{~N}$ & $\mathrm{~N}$ & $\mathrm{~N}$ \\
\hline 8 & TES & 8 & 80 & $\mathrm{~N}$ & $\mathrm{~N}$ & $\mathrm{~N}$ & 0,13 & $\mathrm{~N}$ \\
\hline 9 & TES & $\mathrm{N}$ & 80 & 0,12 & 0,12 & $\mathrm{~N}$ & $\mathrm{~N}$ & $\mathrm{~N}$ \\
\hline 10 & TES & 8 & 80 & $\mathrm{~N}$ & $\mathrm{~N}$ & $\mathrm{~N}$ & $\mathrm{~N}$ & 5 \\
\hline 11 & TES & 8 & $\mathrm{~N}$ & 0,12 & $\mathrm{~N}$ & $\mathrm{~N}$ & $\mathrm{~N}$ & $\mathrm{~N}$ \\
\hline 12 & TES & $\mathrm{N}$ & 80 & -- & -- & -- & -- & -- \\
\hline 13 & TES & $\mathrm{N}$ & -- & -- & -- & -- & -- & -- \\
\hline 14 & TES & -- & 160 & -- & -- & -- & -- & -- \\
\hline 15 & TES & $\mathrm{N}$ & 80 & -- & -- & -- & -- & -- \\
\hline 16 & TES & $\mathrm{N}$ & $\mathrm{N}$ & -- & -- & -- & -- & -- \\
\hline 17 & TES & $\mathrm{N}$ & 320 & -- & -- & -- & -- & -- \\
\hline 18 & TES & -- & 160 & -- & -- & -- & -- & -- \\
\hline 19 & TES & -- & 80 & -- & -- & -- & -- & -- \\
\hline 20 & TES & -- & 320 & -- & -- & -- & -- & -- \\
\hline 21 & TES & -- & 160 & -- & -- & -- & -- & -- \\
\hline $\begin{array}{l}-- \text { test not pe } \\
N \text { - negative } \\
\text { PMNP - Pant } \\
\text { TES - Taiamã } \\
\text { SFIMT - Sim } \\
\text { RFFIT - Rapic }\end{array}$ & $\begin{array}{l}\text { med } \\
\text { I Matogro } \\
\text { logical St } \\
\text { ed Fluores } \\
\text { orescent }\end{array}$ & $\begin{array}{l}\text { e Nation } \\
\text { nhibitio } \\
\text { Inhibiti }\end{array}$ & otest & & & & & \\
\hline
\end{tabular}




\section{Results}

The 21 captured jaguars ( 11 males and 10 females) were in good overall health, except for one animal (jaguar \#1), which showed low body weight and dermatological signs of systemic disease and died 45 days after capture. Unfortunately, it was not possible to correlate this death with any of the diseases examined in this study. All the animals were considered adults based on teeth condition and color, with estimated ages ranging from four to 10 years.

Three of the 14 animals tested for CDV by the virus neutralization assay were positive (21.4\%), with titers of eight. On the other hand, 15 of 17 samples (88.2\%) were positive for CPV, with titers ranging from 80 to 320 . Considering the presence of virus neutralizing antibodies (VNA) sera titers $\geq 0.10$ $\mathrm{IU} / \mathrm{ml}$, three jaguars had positive titers in each test (27.3\%), but only one jaguar showed rabiesneutralizing antibodies in both the SFIMT and RFFIT. Only one of the eleven jaguars (9.1\%) was serologically positive for EEEV and no jaguar was positive for WEEV or VEEV antigens. Table 1 lists the positive results of the serological assay. No animal tested by the RT-PCR assay was positive for WNV and IV.

\section{Discussion}

Many zoonotic viruses are transmitted by means of an infected arthropod vector, by inhalation or conjunctival contact with infected excretions, or by direct contact with infected animals. Despite the healthy appearance of most of the captured animals, the results of this study showed that free-living jaguars from the northern Pantanal are exposed to CDV, parvovirus, rabies and EEEV.

\section{Canine Distemper Virus}

Only three samples from animals captured at Taiamã Ecological Station showed low titers for CDV (titers of $8 \mathrm{VNU}$ ). The prevalence of antibodies against CDV $(21,4 \%)$ found in our study was lower than that reported by Furtado et al. (2013) for jaguars in the southern Pantanal and by Nava et al. (2008) in Atlantic Forest. Jorge et al. (2010) found a higher prevalence of antibodies against CDV (75\%) in ocelots (Leopardus pardalis) in another protected area in the northern Pantanal, but only one puma (Puma concolor) (14,5\%) tested positive in a serological assay in the same study. In all these cases, domestic dogs in the surrounding areas showed high prevalence rates, suggesting this is the route of transmission of this agent to wild carnivores that have been surveyed. Outbreaks of CDV have been reported in wild lions in the Serengeti, Tanzania, in 1994 (ROELKE-PARKER et al., 1996), and high mortality rates have been reported among big cats in captivity in a zoo in the United States, including a jaguar, lions (Panthera leo), tigers (Panthera tigris), and leopards (Panthera pardus), which showed signs of respiratory, enteric and central nervous system disorders (APPEL et al., 1994). Nevertheless, all the positive jaguars in the present study were healthy, without clinical signs of the disease during their capture; hence, the low titers against CDV found in three jaguars only point to occasional exposure to the virus. Although the circulating antibodies found in wild felids in previous studies in Brazil may have been acquired by association with domestic dogs, the exposure of jaguars to CDV in the present study area suggests further investigations about the transmission chain, given their rare contact with domestic dogs. The Taiamã Ecological Station is an island surrounded by extensive flooded areas which comprising a privately owned nature reserve (RPPN JUBRAN), constituting a buffer zone that hinders the access of domestic animals coming from nearby farms. Even considering the large size of the area occupied by jaguars, CDV affects an expanding range of host species (TERIO; CRAFT, 2013; VIANA et al., 2015) and interspecies interactions within wildlife must also be considered in the dynamics of the disease in natural ecosystems such as the region of the Taiamã Ecological Station, given the possibility of virus transmission during predation and/or scavenging of carcasses.

Braz. J. Vet. Res. Anim. Sci., São Paulo, v. 53, n. 3, p. 270-279, 2016 


\section{Parvovirus}

A phylogenetic analysis of data on cross-species transmission among carnivore hosts reveals a significant biodiversity of parvoviruses in nondomestic animals (ALLISON et al., 2013), and parvoviruses have been reported in several wild canid species around the world, including South America (STEINEL et al., 2001; CURI, 2005; DEEM; EMONNS, 2005; FIORELLO et al., 2007; HÜBNER et al., 2010). Our findings demonstrate a high prevalence of antibodies against parvovirus (88\%). Feline parvovirus has been implicated in the mortality of wild captive felids since the early 1940s (TORRES, 1941; GOSS, 1948). A high prevalence of antibodies against parvoviruses (48\%) was detected in free-living wild cats by Filoni et al. (2006), among them two pumas ( $P$. concolor) captured in the Pantanal region. Jorge et al. (2010) found $100 \%$ positivity in seven freeliving pumas captured on a private reserve in the northern Pantanal as well as $75 \%$ of positive samples from ocelots ( $L$. pardalis), indicating the presence of this agent in this region. In the latter study, similarly to CDV, the exposure was attributed to contact with domestic carnivores, although no signs of the disease were found in either the domestic or non-domestic carnivores examined. The high prevalence found in the present study may be explained by the stability of parvovirus in the environment, which precludes the need for direct contact between carnivores for efficient transmission, although cross-species transmission by predator-prey relationships must be considered (ALLISON et al., 2013). The absence of signs at the time of capture reflects the characteristics of the virus, which usually causes disease in juveniles, but shows only subclinical signs in adults. Particular attention should focus on the highest titers found in two adult females (animals \#17 and \#21; $\mathrm{T}=320$ ), in view of evidence of the negative effects on pup survival, and hence, on population growth (MECH et al., 2008).

\section{Rabies virus}

This zoonotic viral disease kills thousands of humans and animals around the world each year. In recent decades, rabies has been considered a potential threat to the conservation of wild carnivore populations (SILLERO-ZUBIRI et al., 1996; FLACKE et al., 2013), as well as a new public health concern (BERNARDI et al., 2005). Today, surveillance of the virus in wildlife is an important tool for epidemiological assessments that may underpin the development of disease prevention and control strategies. Titers of VNA $\geq 0.50 \mathrm{IU} / \mathrm{mL}$ indicate protective response after human or animal rabies vaccination, but presence of lower titers may indicate immune response to virus antigens by immunization or natural infection (WHO, 2013). Low titers of rabies virus neutralizing antibodies have been detected in other wild carnivore species, including apparently healthy free-living jaguars (JORGE et al., 2010; FURTADO et al., 2013), suggesting non-lethal infection. In our study, we were unable to correlate or presume the cause of death of jaguar \#1, 45 days after its capture, which showed the highest titer of rabiesneutralizing antibodies and was reactive in both tests, avoiding the possibility of nonspecific inhibition or false positive result. Therefore, inferences about the possible effects of the virus on this animal's health could not be made. Although some wild animal species are known to act as reservoirs of rabies, suggesting the existence of a sylvatic cycle independent on domestic dogs (Cerdocyon thousCARNIELI JUNIOR et al., 2008), to the best of our knowledge, nothing is known about the role of wild felids in the epidemiology of rabies in nature. On the other hand, transmission via predation and ingestion of contaminated carcasses seems a more likely route, which in turn may lead only to the production of neutralizing antibodies (RAMSDEN; JOHNSTON, 1975). Prevalence in free-living jaguars requires 
further investigations as this feline species is protected by an epidemiological peculiarity, the viral strain that occurs in jaguars must be better evaluated and epidemiological characteristics such as the route of infection must be determined. Genotypic and phylogenetic analyses of rabies virus that occurs in jaguars could be interesting to clarify questions about rabies in the Brazilian Pantanal.

\section{Equine Encephalomyelitis virus}

The environmental characteristics of the Pantanal biome offer favorable ecological conditions for the maintenance of EEEV, WEEV and VEEV due to the presence of insect vectors and a variety migratory birds from other regions of the world, which are thought to be the main reservoir hosts in natural cycles (VASCONCELOS et al., 1991), although some small mammals (e.g., rodents) may also amplify EEEV (WEAVER at al., 2004). Antibodies against EEEV were detected in one individual (jaguar \#10), with no correlated signs of the disease during the capture procedures. The serum containing antibodies was retested and the titer of 1:5 was confirmed (data not shown). Given the small number of sampled animals, it is difficult to interpret this single positive sample. Moreover, the particular interactions between environment, wildlife and people in this flooded area, in addition to reports of the circulation of this virus in horses (MELO et al., 2012) require further studies to support surveillance programs of the disease and to predict EEEV outbreaks. As far as we know, there is no previous report of EEE infection in captive or freeliving Brazilian Neotropical felids.

\section{West Nile and Influenza virus}

None of the jaguars in this study were positive for WNV or IV. The impact of migratory birds as potential carriers of infectious diseases such as WNV and IV underscores the importance of conducting studies to cope with public health emergencies of an international scope. Wetland ecosystems such as the
Pantanal have been described as natural focuses of WNV infections since the late seventies (JOUBERT et al., 1970). Periodical outbreaks of WNV encephalitis in the USA (LINDSEY et al., 2010; MCMULLEN et al., 2011) and serological evidence in South American countries (MATTAR et al., 2005; BOSCH et al., 2007; DIAZ et al., 2008) create demands in the field of epidemiology to search for evidence of WNV circulating in Brazil. Likewise, the negative impact of IV on the economy due to trade restrictions and the broad spectrum of migratory bird species that may be affected point to the need for renewed efforts to improve the strategies of surveillance programs. This is particularly relevant in light of the fact that clinical signs of avian influenza (H5N1) were reported in two tigers (Panthera tigris) and two leopards ( $P$. pardus) at a zoo in Suphanburi, Thailand, that had been fed with infected poultry carcasses (KEAWCHAROEN et al., 2004). This emphasizes the need for further investigations of the role of felids in the epidemiology of avian influenza and its implications for human health, poultry and wildlife conservation. Although the PCR results of this study were negative, serological surveys could be conducted to evaluate the possible movement of such viral agents in the region, based on epidemiological research that takes into account the specificities of this biome.

\section{Conclusion}

In view of the findings of this study, it is unlikely that the viruses examined here represent a threat to the jaguar populations in this region. However, given the potential of CDV, parvovirus and rabies to cause outbreaks, constant monitoring is needed by means of adaptive management to prevent population declines and implications for public health. Equally important is to include the evaluation of environments such as the Pantanal biome, which presents vulnerabilities and harbors potential reservoirs for diseases, in zoonotic disease surveillance programs. 


\section{Acknowledgements}

We thank CENAP/ICMBio (National Research Center for the Conservation of Carnivorous Mammals) for its financial and technical support in the capture of animals; and the Brazilian agencies CAPES (Federal Agency for the Support and Improvement of Higher Education) (1913/2011), FAPEMAT (Research Support Foundation of the State of Mato Grosso)
(263287/2010) and $\mathrm{CNPq}$ (National Council for Scientific and Technological Development) (472206/2011-7) for their financial support. We also thank CAPES, FAPESP and CNPq for scholarships awarded to I.I.G. Taques and T. Ometto and for Scientific Productivity Grants awarded to A.A. Alfieri and D.M. Aguiar.

\section{References}

ALLISON, A. B.; KOHLER, D. J.; FOX, K. A.; BROWN, J. D.; GERHOLD, R. W.; SHEARN-BOCHSLER, V. I.; DUBOVI, E. J.; PARRISH, C. R.; HOLMES, E. C. Frequent cross-species transmission of parvoviruses among diverse carnivore hosts. Journal of Virology, v. 87, n. 4, p. 23422347, 2013. doi: 10.1128/JVI.02428-12.

APPEL, M. J. G.; ROBSON, D. S. A microneutralization test for canine distemper virus. American Journal of Veterinary Research, v. 34, n. 11, p. 1459-1463, 1973.

APPEL, M. J. G.; YATES, R. A.; FOLEY, G. L.; BERNSTEIN, J. J.; SANTINELLI, S.; SPELMAN, L. H.; MILER, L. D.; ARP, L. H.; ANDERSON, M.; BARR, M.; PEARCE-KELLING, S.; SUMMERS, B. A. Canine distemper enzootic in lions, tigers, and leopards in North America. Journal of Veterinary Diagnostic Investigation, v. 6, n. 3, p. 277-288, 1994. doi: $10.1177 / 104063879400600301$.

ARAÚJO, J.; AZEVEDO JUNIOR, S. M.; GAIDET, N.; HURTADO, R. F.; WALKER, D.; THOMAZELLI, L. M.; OMETTO, T.; SEIXAS, M. M. M.; RODRIGUES, R.; GALINDO, D. B.; SILVA, A. C. S.; RODRIGUES, A. M. M.; BOMFIM, L. L.; MOTA, M. A.; LARRAZÁBAL, M. E.; BRANCO, J. O.; SERAFINI, P.; NETO, I. S.; FRANKS, J.; WEBBY, R. J.; WEBSTER, R. G.; DURIGON, E. L. Avian influenza virus (H11N9) in migratory shorebirds wintering in the Amazon Region, Brazil. PLoS ONE, v. 9, n. 10, p. e110141, 2014. doi: 10.1371/journal.pone.0110141.

BERNARDI, F.; NADIN-DAVIS, S. A.; WANDELER, A. I.; ARMSTRONG, J.; GOMES, A. A. B.; LIMA, F. S.; NOGUEIRA, F. R. B.; ITO, F. H. Antigenic and genetic characterization of rabies viruses isolated from domestic and wild animals of Brazil identifies the hoary fox as a rabies reservoir. Journal of General Virology, v. 86, p. 3153-3162, 2005. doi: 10.1099/vir.0.81223-0.

BOSCH, I.; HERRERA, F.; NAVARRO, J. C.; LENTINO, M.; DUPUIS, A.; MAFFEI, J.; JONES, M.; FERNÁNDEZ, E.; PÉREZ, N.; PÉREZ-EMÁN, J.; GUIMARÃES, A. E.; BARRERA, R.; VALERO, N.; RUIZ, J.; VELÁSQUEZ, G.; MARTINEZ, J.; COMACH, G.; KOMAR, N.; SPIELMAN, A.; KRAMER, L. West Nile virus, Venezuela. Emerging Infectious Diseases, v. 13, n. 4, p. 651-653, 2007. doi: 10.3201/eid1304.061383.

CARMICHEAL, L. E.; JOUBERT, J. C.; POLLOCK, R. V. H. Hemagglutination by canine parvovirus: Serologic studies and diagnostic applications. American Journal of Veterinary Research, v. 4, n.1, p. 784-790, 1980.

CARNIELI JUNIOR, P.; FAHL, W. O.; CASTILHO, J. G.; OLIVEIRA, R. N. O.; MACEDO, C. I.; DURYMANOVA, E.; JORGE, R. S. P.; MORATO, R. G.; SPÍNDOLA, R. O.; MACHADO, L. M.; SÁ, J. E. U.; CARRIERI, M. L.; KOTAIT, I. Characterization of Rabies virus isolated from canids and identification of the main wild canid host in Northeastern Brazil. Virus Research, v. 131, n. 1, p. 33-46, 2008. doi: 10.1016/j.virusres.2007.08.007.

CHILDS, J. E. Zoonotic viruses of wildlife: hither from yon. Archives of Virology, Supplementum, v. 18, p. 1-11, 2004. Supplement. doi: 10.1007/978-3-7091-0572-6_1.

COURTENAY, O.; QUINNELL, R. J.; CHALMERS, W. S. K. Contact rates between wild and domestic canids: no evidence of parvovirus or canine distemper virus in crabeating foxes. Veterinary Microbiology, v. 81, n. 1, p. 9-19, 2001. doi: 10.1016/S0378-1135(01)00326-1.

CURI, N. Avaliação do estado de saúde e do risco de transmissão de doenças entre canídeos (Mammalia, Carnivora) silvestres e domésticos na Serra do Cipó, Minas Gerais: implicações para a conservação. 2005. $101 \mathrm{f}$. Dissertação (Mestrado em Zoologia de Vertebrados) - 
Pontifícia Universidade Católica de Minas Gerais, Belo Horizonte, 2005.

DAOUST, P. Y.; MCBURNEY, S. R.; GODSON, D. L.; VAN DE BILDT, M. W. G.; OSTERHAUS, A. D. M. E. Canine distemper virus-associated encephalitis in freeliving Lynx (Lynx canadensis) and Bobcats (Lynx rufus) of eastern Canada. Journal of Wildlife Disease, v. 45, n. 3, p. 611-624, 2009. doi: 10.7589/0090-3558-45.3.611.

DEEM, S. L.; EMMONS, L. H. Exposure of free-ranging maned wolves (Chrysocyon brachyurus) to infectious and parasites disease agents in the Nöel Kempff Mercado National Park, Bolivia. Journal of Zoo and Wildlife Medicine, v. 36, n. 2, p. 192-197, 2005. doi: 10.1638/04076.1.

DIAZ, L. A.; KOMAR, N.; VISINTIN, A.; JÚRI, M. J. D.; STEIN, M.; ALLENDE, R. L.; SPINSANTI, L.; KONIGHEIM, B.; AGUILAR, J.; LAURITO, M.; ALMIRÓN, W.; CONTIGIANI, M. West Nile virus in birds, Argentina. Emerging Infectious Diseases, v. 14, n. 4, p. 689-691, 2008. doi: 10.3201/eid1404.071257.

FAVORETTO, S. R.; CARRIERI, M. L.; TINO, M. S.; ZANETTI, C. R.; PEREIRA, O. A. Simplified fluorescent inhibition microtest for the titration of rabies neutralizing antibodies. Revista do Instituto de Medicina Tropical de São Paulo, v. 35, n. 2, p. 171-175, 1993. doi: 10.1590/S003646651993000200009.

FILONI, C.; CATÃO-DIAS, J. L.; BAY, G.; DURIGON, E. L.; JORGE, R. S. P.; LUTZ, H.; HOFMANN-LEHMANN, R. First evidence of feline herpesvirus, calicivirus, parvovirus, and ehrlichia exposure in Brazilian freeranging felids. Journal of Wildlife Disease, v. 42, n. 2, p. 470-477, 2006. doi: 10.7589/0090-3558-42.2.470.

FIORELLO, C. V.; NOSS, A. J.; DEEM, S. L.; MAFFEI, L.; DUBOVI, E. J. Serosurvey of small carnivores in the Bolivian Chaco. Journal of Wildlife Diseases, v. 43, n. 3, p. 551-557, 2007. doi: 10.7589/0090-3558-43.3.551.

FLACKE, G.; BECKER, P.; COOPER, D.; GUNTHER, M. S.; ROBERTSON, I.; HOLYOAKE, C.; DONALDSON, R.; WARREN, K. An infectious disease and mortality survey in a population of free-ranging African wild dogs and sympatric domestic dogs. International Journal of Biodiversity, v. 2013, p. 1-9, 2013. doi: 10.1155/2013/497623.

FURTADO, M. M.; RAMOS FILHO, J. D.; SCHEFFER, K. C; COELHO, C. J.; CRUZ, P. S.; IKUTA, C. Y.; JÁCOMO, A. T. A.; PORFÍRIO, G. E. O.; SILVEIRA, L.; SOLLMANN,
R.; TÔRRES, N. M.; FERREIRA NETO, J. S. Serosurvey for selected viral infections in free-ranging jaguars (Panthera onca) and domestic carnivores in Brazilian Cerrado, Pantanal, and Amazon. Journal of Wildlife Diseases, v. 49, n. 3, p. 510-521, 2013. doi: 10.7589/2012-02-056.

GOSS, L. J. Species susceptibility to the viruses of Carré and feline enteritis. American Journal of Veterinary Research, v. 9, p. 65-68, 1948.

HÜBNER, S. O.; PAPPEN, F. G.; RUAS, J.; VARGAS, G. D.; FISCHER, G.; VIDOR, T. Exposure of pampas fox (Pseudalopex gymnocercus) and crab-eating fox (Cerdocyon thous) from the Southern region of Brazil to Canine distemper virus (CDV), Canine parvovirus (CPV) and Canine coronavirus (CCoV). Brazilian Archives of Biology and Technology, v. 53, n. 3, p. 593-597, 2010. doi: 10.1590/S1516-89132010000300012.

JORGE, R. S. P.; PEREIRA, M. S.; MORATO, R. G.; SCHEFFER, K. C.; CARNIELI JUNIOR, P.; FERREIRA, F.; FURTADO, M. M.; KASHIVAKURA, C. K.; SILVEIRA, L.; JÁCOMO, A. T. A.; LIMA, E. S.; PAULA, R. C.; MAYJUNIOR, J. A. Detection of rabies virus antibodies in Brazilian free-ranging wild carnivores. Journal of Wildlife Disease, $v$. 46, n. 4, p. 1310-1315, 2010. doi: 10.7589/0090-3558-46.4.1310.

JOUBERT, L.; OUDAR, J.; HANNOUN, C.; BEYTOUT, D.; CORNIOU, B.; GUILLON, J. C.; PANTHIER, R. Epidemiology of the West Nile virus: study of a focus in Camargue. IV. Meningo-encephalomyelitis of the horse. Annales de 1 Institut Pasteur, v. 118, p. 239-247, 1970.

KEAWCHAROEN, J.; ORAVEERAKUL, K.; KUIKEN, T.; FOUCHIER, R. A. M.; AMONSIN, A.; PAYUNGPORN, S.; NOPPORNPANTH, S.; WATTANODORN, S.; THEAMBOONLERS, A.; TANTILERTCHAROEN, R.; PATTANARANGSAN, R.; ARYA, N.; RATANAKORN, P.; OSTERHAUS, A. D. M. E.; POOVORAWAN, Y. Avian influenza $\mathrm{H} 5 \mathrm{~N} 1$ in tigers and leopards. Emerging Infectious Diseases, v. 10, n. 12, p. 2189-2191, 2004. doi: 10.3201/eid1012.040759.

KOTAIT, I.; PEIXOTO, Z. M. P.; COIMBRA, T. L. M.; CUNHA, E. M. S.; QUEIROZ, L. H.; MACRUZ, R.; NAGAMORI, A. H. Isolamento e identificação do vírus da encefalomielite equina, tipo leste, em equinos do Estado de São Paulo, Brasil. Arquivos do Instituto Biológico, v. 59, n. 1-2, p. 37-41, 1992.

LINDSEY, N. P.; STAPLES, J. E.; LEHMAN, J. A.; FISCHER, M. Surveillance for human West Nile virus 
disease - United States, 1999-2008. MMWR Surveillance Summaries, v. 59, p. 1-17, 2010.

MAMEDE, S. B.; ALHO, C. J. R. Response of wild mammals to seasonal shrinking-and-expansion of habitats due to flooding regime of the Pantanal, Brazil. Brazilian Journal of Biology, v. 66, n. 4, p. 991-998, 2006. doi: 10.1590/S1519-69842006000600006.

MATTAR, S.; EDWARDS, E.; LAGUADO, J.; GONZÁLEZ, M.; ALVAREZ, J.; KOMAR, N. West Nile virus antibodies in Colombian horses. Emerging Infectious Diseases, v. 11, n. 9, p. 1497-1498, 2005. doi: 10.3201/eid1109.050426.

MCMULLEN, A. R.; MAY, F. J.; LI, L.; GUZMAN, H.; BUENO JR., R.; DENNETT, J. A.; TESH, R. B.; BARRETT, A. D. Evolution of new genotype of West Nile virus in North America. Emerging Infectious Diseases, v. 17, n. 5, p. 785-793, 2011. doi: 10.3201/eid1705.101707.

MECH, L. D.; GOYAL, S. M.; PAUL, W. J.; NEWTON, W. E. Demographic effects of canine parvovirus on a freeranging wolf population over 30 years. Journal of Wildlife Disease, v. 44 , n. 4 , p. $824-836$, 2008. doi: 10.7589/00903558-44.4.824

MELO, R. M.; CAVALCANTI, R. C.; VILLALOBOS, E. M. C.; CUNHA, E. M. S.; LARA, M. C. C. S. H.; AGUIAR, D. M. Ocorrência de equídeos soropositivos para os vírus das encefalomielites e anemia infecciosa no estado de Mato Grosso. Arquivos do Instituto Biológico, v. 79, n. 2, p. 169-175, 2012. doi: 10.1590/S1808-16572012000200004.

MUNSON, L.; TERIO, K. A.; KOCK, R.; MLENGEYA, T.; ROELKE, M. E.; DUBOVI, E.; SUMMERS, B.; SINCLAIR, A. R. E.; PACKER, C. Climate extremes promote fatal coinfections during canine distemper epidemics in african lions. PLoS One, v. 3, n. 6, p. e2545, 2008. doi: 10.1371/journal.pone.0002545.

NAVA. A. F. D.; CULLEN, L.; SANA, D. A.; NARDI, M. S.; RAMOS FILHO, J.; LIMA, T. F.; ABREU, K. C.; FERREIRA, F. First evidence of canine distemper in Brazilian free-ranging felids. Ecohealth, v. 5, p. 513-518, 2008. doi: 10.1007/s10393-008-0207-8.

OMETTO, T.; DURIGON, E. L.; ARAUJO, J.; APRELON, R.; AGUIAR, D. M.; CAVALCANTE, G. T.; MELO, R. N.; LEVI, J. E; AZEVEDO JR, S. M.; PETRY, M. V.; NETO, I. S.; SERAFINI, P.; VILLALOBOS, E.; CUNHA, E. M. S.; LARA, M. C. C. S. H.; NAVA, A. F. D.; NARDI, M. S.; HURTADO, R.; RODRIGUES, R.; SHERER, A. L.; SHERE,
J. F. M.; GERALDI, M. P.; SEIXAS, M. M. M.; PETERKA, C.; BANDEIRA, D. S.; PRADEL, J.; VACHIERY, N.; LABRUNA, M. B.; CAMARGO, L. M. A.; LANCIOTTI, R.; LEFRANÇOIS, T. West Nile virus surveillance, Brazil, 2008-2010. Transactions of the Royal Society of Tropical Medicine and Hygiene, v. 107, n. 11, p. 723-730, 2013. doi: $10.1093 /$ trstmh/trt081.

RAMSDEN, R. O.; JOHNSTON, D. H. Studies on the oral infectivity of rabies virus in carnivora. Journal of Wildlife Diseases, v. 11, n. 3, p. 318-324, 1975. doi: 10.7589/00903558-11.3.318.

ROELKE-PARKER, M. E.; MUNSON, L.; PACKER, C.; KOCK, R.; CLEAVELAND, S.; CARPENTER, M.; O'BRIEN, S. J.; POSPISCHIL, A.; HOFMANNLEHMANN, R.; LUTZ, H.; MWAMENGELE, G. L. M.; MGASA, M. N.; MACHANGE, G. A.; SUMMERS, B. A.; APPEL, M. J. H. A canine distemper virus epidemic in Serengeti lions (Panthera leo). Nature, v. 379, n. 6564, p. 441-445, 1996. doi: 10.1038/379441a0.

SEIMON, T. A.; MIQUELLE, D. G.; CHANG, T. Y.; NEWTON, A. L.; KOROTKOVA, I.; IVANCHUK, G.; LYUBCHENKI, E.; TUPIKOV, A.; SLABE, E.; MCALOOSE, D. Canine distemper virus: an emerging disease in wild endangered amur tigers (Panthera tigris altaica). mBio, v. 4, n. 4, p. e00410-13, 2013. doi: 10.1128/mBio.00410-13.

SILLERO-ZUBIRI, C.; KING, A. A.; MACDONALD, D. W. Rabies and mortality in Ethiopian wolves (Canis simensis). Journal of Wildlife Diseases, v. 32, n. 1, p. 80-86, 1996. doi: 10.7589/0090-3558-32.1.80.

SMITH, J. S.; YAGER, P. A.; BAER, G. M. A rapid fluorescente focus inhibition test (RFFIT) for determining rabies virus neutralizing antibodies. In: MESLIN, F. X.; KAPLAN, M. M.; KOPROWSKY, H. Laboratory techniques in rabies. 4. ed. Geneva: World Health Organization, 1996. p. 181-192.

STEINEL, A.; PARRISH, C. R.; BLOOM, M. E.; TRUYEN, U. Parvovirus infections in wild carnivores. Journal of Wildlife Disease, v. 37, n. 3, p. 594-607, 2001. doi: 10.7589/0090-3558-37.3.594.

TERIO, K. A.; CRAFT, M. E. Canine distemper virus (CDV) in another big cat: should CDV be renamed carnivore distemper virus? mBio, v. 4, n. 5, p. e00702-13, 2013. doi: 10.1128/mBio.00702-13.

TORRES, S. Infectious feline gastroenteritis in wild cats. North American Veterinarian, v. 22, p. 297-299, 1941. 
VASCONCELOS, P. F. C.; TRAVASSOS DA ROSA, J. F. S.; TRAVASSOS DA ROSA, A. P. A.; DEGALLIER N.; PINHEIRO, F. P.; SÁ FILHO, G. C. Epidemiologia das encefalites por arbovírus na Amazônia brasileira. Revista do Instituto de Medicina Tropical de São Paulo, v. 33, n. 6, p. 465-476, 1991. doi: 10.1590/S0036-46651991000600007.

VIANA, M.; CLEAVELAND, S.; MATTHIOPOULOS, J.; HALLIDAY, J.; PACKER, C.; CRAFT, M. E.; HAMPSON, K.; CZUPRYNA, A.; DOBSON, A. P.; DUBOVI, E. J.; ERNEST, E.; FYUMAGWA, R.; HOARE, R.; HOPCRAFT, J. G. C.; HORTON, D. L.; KAARE, M. T.; KANELLOS, T.; LANKESTER, F.; MENTZEL, C.; MLENGEYA, T.; MZIMBIRI, I.; TAKAHASHI, E.; WILLETT, B.; HAYDON, D. T.; LEMBO, T. Dynamics of a morbillivirus at the domestic-wildlife interface: canine distemper virus in domestic dogs and lions. Proceedings of the National Academy of Sciences of the United States of America, v. 112 , n. 5, p. 1464-1469, 2015. doi: 10.1073/pnas.1411623112.

WEAVER, S. C.; FERRO, C.; BARRERA, R.; BOSHELL, J.; NAVARRO, J. C. Venezuelan equine encephalitis. Annual Review of Entomology, v. 49, p. 141-174, 2004. doi: 10.1146/annurev.ento.49.061802.123422.

WILLIAMS, E. S. Canine Distemper. In: WILLIAMS, E. S.; BARKER, I. K. Infectious diseases of wild mammals. 3. ed. Ames: Iowa State University Press, 2001. p. 50-59.

WORLD HEALTH ORGANIZATION (WHO). Expert consultation on rabies: second report. Technical report series 982. Geneva: World Health Organization, 2013. 150 p. 